\title{
The characteristics of woody debris and sediment distribution in headwater streams, southeastern Alaska
}

\author{
Takashi Gomi, Roy C. Sidle, Mason D. Bryant, and Richard D. Woodsmith
}

\begin{abstract}
Large woody debris (LWD), fine woody debris (FWD), fine organic debris (FOD), and sediment deposition were measured in 15 steep headwater streams with five management and disturbance regimes. Clear-cut channels logged in 1995 contained large accumulations of logging residue that initially provided sites for sediment storage. Half of the LWD in clear-cut channels was recruited during and immediately after logging. Woody debris from logging activities remains in young growth conifer channels 37 years after logging. Numbers of LWD in clear-cut and young conifer channels were significantly higher than in old-growth channels, although numbers of FWD pieces were not significantly different because of higher recruitment from old-growth stands. Channels that experienced recent (1979 and (or) 1993) and earlier (1961 and (or) 1979) scour and runout of landslides and debris flows contained less LWD and FWD, although large volumes of LWD and FWD were found in deposition zones. The volumes of sediment stored in young alder and recent landslide channels were higher than in the other channels. Because of the recruitment of LWD and FWD from young alder stands, the ratio of sediment stored behind woody debris to total sediment volume was higher in young alder channels compared with recent landslide channels. Numbers of LWD and FWD pieces in all streams were significantly correlated with the volumes of sediment stored behind woody debris. Timber harvesting and soil mass movement influence the recruitment, distribution, and accumulation of woody debris in headwater streams; this modifies sediment storage and transport in headwater channels.
\end{abstract}

Résumé : Les débris ligneux grossiers (DLG), les débris ligneux fins (DLF), les débris organiques fins (DOF) et le dépôt de sédiments ont été mesurés dans 15 têtes de rivière escarpées avec cinq régimes d'aménagement et de perturbation. Des vallées coupées à blanc en 1995 contenaient d'importantes accumulations de résidus de coupe qui ont initialement fourni des sites pour la rétention des sédiments. La moitié des DLG dans les vallées coupées à blanc ont été accumulés pendant et immédiatement après la coupe. Les débris ligneux provenant des activités de récolte persistent dans les vallées avec une régénération de conifères 37 ans après la coupe. Le nombre de DLG dans les vallées coupées à blanc et les vallées avec de jeunes conifères est significativement plus élevé que dans les vallées de vieille forêt, quoique que le nombre de morceaux de DLF n'ait pas été significativement différent à cause du recrutement plus élevé dans les peuplements de vieille forêt. Les vallées qui ont subi de récents (1979 et (ou) 1993) et plus vieux (1961 et (ou) 1979) décapages et écoulements suite à des glissements de terrain et des mouvements de débris contenaient moins de DLG et DLF, bien que d'importants volumes de DLG et DLF aient été retrouvés dans les zones de déposition. Le volume de sédiments retenus dans les vallées couvertes de jeunes aulnes et celles qui avaient récemment subi des glissements de terrain était plus important que dans les autres vallées. À cause du recrutement de DLG et DLF dans les jeunes peuplements d'aulne, le rapport des sédiments retenus derrière les débris ligneux sur le volume total de sédiments était plus élevé dans les vallées couvertes de jeunes aulnes que dans les vallées qui avaient récemment subi un glissement de terrain. Le nombre de morceaux de DLG et de DLF dans toutes les vallées était significativement corrélé avec le volume de sédiments retenus derrière les débris ligneux. La récolte du bois et les mouvements de masse $\mathrm{du}$ sol influencent le recrutement, la distribution et l'accumulation des débris ligneux dans les têtes de rivière; cela modifie le stockage et le transport des sédiments dans les têtes de rivière.

[Traduit par la Rédaction]

Received September 3, 2000. Accepted April 6, 2001. Published on the NRC Research Press Web site at http://cjfr.nrc.ca on July 25, 2001.

T. Gomi. Forest Resources Management, 2nd Floor, Forest Science Center, 2424 Main Mall, University of British Columbia, Vancouver, BC V6T 1Z4, Canada.

R.C. Sidle. ${ }^{1}$ Department of Geography, The National University of Singapore, 1 Arts link, Kent Ridge, 117570, Singapore.

M.D. Bryant and R.D. Woodsmith. Pacific Northwest Research Station, USDA Forest Service, 2770 Sherwood Lane, Suite 2A, Juneau, AK 99801, U.S.A.

${ }^{1}$ Corresponding author (e-mail: geosrc@nus.edu.sg). 


\section{Introduction}

A number of studies during last three decades have demonstrated the biological and geomorphological importance of woody debris in forested streams (e.g., Harmon et al. 1986; Bisson et al. 1987). Woody debris can alter flow velocity and direction and, thus, exert control over sediment and organic matter transport as well as stream geomorphology (Woodsmith and Swanson 1997). Therefore, woody debris modifies the structure and abundance of habitat as well as provides a source of nutrients for stream biota (Bilby and Ward 1989; Inoue and Nakano 1998). Woody debris also forms steps and modifies the hydraulics of mountain stream channels (Heede 1972). Changes in the abundance of woody debris in streams control sediment movement (Megahan 1982; Nakamura and Swanson 1993; Bovis et al. 1998), pool spacing (Montgomery et al. 1995), and streambed composition (Sidle and Sharma 1996; Woodsmith and Buffington 1996).

Timber harvesting and related landslides and debris flows strongly affect stream geometry and the persistence of woody debris (Bisson et al. 1987). Higher volumes of woody debris were found in unlogged streams compared with logged streams in the Appalachian Mountains (Hedman et al. 1996). Similarly, recent research in the Pacific Northwest observed reduced numbers of woody debris pieces in streams after logging (Bilby and Ward 1991). In contrast, earlier research in the Pacific Northwest showed that the numbers of woody debris pieces increased after logging because of logging slash and unmerchantable timber (Froehlich 1973; Bryant 1980). Hogan et al. (1998) indicated that formation of $\log$ jams was related to the history of landslides after logging in the Queen Charlotte Islands, British Columbia.

Both timber harvesting and related soil mass movement can significantly impact headwater streams. Headwater streams are defined as small (bank-full width $<2 \mathrm{~m}$ ), steep gradient $\left(>3^{\circ}\right)$ channels that include first- and second-order streams (Strahler 1957) and zero-order basins (Tsukamoto et al. 1982). While hillslope gullies have relatively deep (3$30 \mathrm{~m}$ ) V-shaped cross sections (Bovis et al. 1998), headwater streams may have either shallow (1-3 m), U-shaped profiles or gullylike profiles. Headwater streams are abundant in mountainous terrain of the Pacific Northwest.

The distribution and accumulation of woody debris in headwater streams may be more directly affected by timber harvesting and related sediment movement than in larger, low-gradient streams. For instance, logging slash and unmerchantable logs remain in the streams after timber harvesting (Froehlich 1973; Millard 2000). Logging roads, which cross headwater streams, often alter stream channels because of culvert installations, modify flow and sediment regimes, and increase landslide probability (Sidle et al. 1985). Wood and sediment are evacuated from upper stream reaches by landslides and debris flows and then redistributed and deposited in downstream reaches (Johnson et al. 2000). Subsequently, pioneer vegetation species rapidly recolonize in both scour and deposition zones, and new woody debris is introduced gradually into headwater channels (Swanson et al. 1998). This newly recruited woody debris provides sites for sediment storage. These processes modify the biological productivity, microinvertebrate habitat, and sediment link- ages from hillslopes to streams and from headwaters to main channels.

Even though various attributes of headwater streams related to biological and physical stream dynamics are recognized, the relative importance of these small channels compared with higher order and fish-bearing streams is often underestimated. Particularly, functional linkages between headwater streams and main channels are poorly understood. A tight biological coupling exists between organic matter inputs and macroinvertebrate habitat in headwater streams (Richardson 1992). Drifting materials (invertebrates and detritus) from headwater streams are important components for food webs in the downstream ecosystems (Wipfli and Gregovich 2001). Portions of headwater streams in lower gradient sections are also important for migration, refugia, and habitat of juvenile fish (Bryant 1984). Sediment movement and floods in headwater systems affect the channel geomorphology and riparian vegetation structure in headwaters and downstream reaches (Swanson et al. 1998). Sediment transport from steep headwaters to downstream is closely related to the sediment storage capacity of woody debris (Megahan 1982; Bovis et al. 1998). Although the river continuum concept (Vannote et al. 1980), which incorporates physical and biological stream attributes, is widely accepted, headwater streams have typically not been included in this conceptual model, supported studies, and management applications. Thus, the influence of timber harvesting on woody debris and sediment dynamics in headwater streams is poorly understood.

The objective of this study is to estimate the influence of different riparian conditions related to timber harvesting and landslide activities (management or disturbance regimes) on woody debris and sediment distributions and their related functions in headwater stream systems. We examined $(i)$ the influences of recent and past timber harvesting on the abundance and distribution of woody debris, (ii) the influences of landslides and debris flows on woody debris abundance and sediment accumulations, and (iii) the in-stream functions of woody debris related to sediment storage.

\section{Study site}

This study was conducted in the Maybeso Experimental Forest and the adjacent Harris River basin in the Tongass National Forest, Prince of Wales Island, southeastern Alaska (Fig. 1). Climate in this area is cool and temperate. The mean annual temperature is $10^{\circ} \mathrm{C}$; mean annual precipitation is $2800 \mathrm{~mm}$. The basins are Ushaped glacial valleys. The valleys are covered by a varying thickness of glacial till that was formed during late Wisconsinan glacial advance (Swanston 1967). Depth of soil plus the thin veneer of glacial till ranges from 0.30 to $1.0 \mathrm{~m}$. Forest vegetation is dominated by western hemlock (Tsuga heterophylla (Raf.) Sarg.), Sitka spruce (Picea sitchensis (Bong.) Carrière), western redcedar (Thuja plicata Donn.), and red alder (Alnus rubra Bong.); however, riparian vegetation is highly influenced by past disturbance regimes. Alder dominates riparian zones that have been disturbed by landslides and debris flows. No residential fish were found in the upper reaches of the headwater streams, although a few juvenile salmonids were found in the lower. The Maybeso Valley was initially logged in 1953 and logging continued until 1957. Timber harvesting was conducted from 1959 to 1961 in the Harris River basin (Meehan et al. 1969). More recent clear-cutting occurred in the Harris River basin in 1995 with relatively smaller cut blocks. 
All harvest units were clear-cut using cable-logging methods on hillslopes.

Five management or disturbance regimes (treatments) in riparian zones of headwater streams were selected based on the history of timber harvesting and landslides and debris flows within the Maybeso Experimental Forest and the Harris River basin (Fig. 1). The five treatments include old-growth $(\mathrm{OG})$; recent (3-year-old) clearcut (CC); young-growth (37 years after clear-cutting) conifer riparian forest (YC); young-growth (40 years after clear-cutting) alder riparian forest (YA); and recent landslide and debris flow channels (LS) (Table 1). Three headwater streams were examined for each of the five treatments giving a total of 15 streams. These treatments are representative of steep glaciated forest landscapes in southeastern Alaska, since they are largely controlled by similar biogeoclimatic factors typical of the area (e.g., vegetation, glaciation, and geology). LS and YA streams were affected by timber harvesting and once or twice by landslides and debris flows in 1961, 1979, and 1993 based on field studies (Swanston 1967; Johnson et al. 2000), aerial photographs taken by USDA Forest Service, and tree ring analysis of trees growing on debris flow deposits. The most recent landslide activity occurred during an October 1993 rainstorm and affected only LS channels. Once landslides initiate, sediment is transported as channelized debris flows and deposited in lower gradient reaches. Debris flows also transport woody debris and newly recruited wood as well as form woody debris jams in the deposition zones. The lower ends of the deposition zones did not reach the main channel of Maybeso Creek because of the wide, flat valley bottom (Fig. 2).

To evaluate the influence of landslides and debris flows on the distribution and accumulation of woody debris, both LS and YA streams were divided into upper (scour and runout) and lower (deposition) sections based on field observations (Fig. 2). Additionally, two CC streams (CC1 and CC2) were divided into upper and lower sections to estimate the effects of a midslope logging road on woody debris and sediment distribution. The effects of landslides and debris flows and subsequent regeneration of riparian stands were evaluated by comparing the LS, YA, and OG streams. Comparing $\mathrm{YC}, \mathrm{CC}$, and $\mathrm{OG}$ streams demonstrates the influence of past and recent timber harvesting in channels with no landslide and debris flow activity during the past few centuries.

The lengths of upper channel reaches range from 100 to $340 \mathrm{~m}$ with mean bank-full widths of 0.6 to $2.8 \mathrm{~m}$ and mean stream gradients of 8.5 to $45.9 \%$ (Table 1). The lengths of lower channel reaches in LS, YA, and CC range from 100 to $400 \mathrm{~m}$ with mean bank-full widths of $0.9-3.7 \mathrm{~m}$ and mean stream gradients of 9.4$32.5 \%$. Elevations from lower to upper ends of study reaches range from 80 to $270 \mathrm{~m}$ in YA and LS, while those in YC, CC, and OG range from 150 to $330 \mathrm{~m}$. Stream channel profiles are only incised 1-3 m. Most of the streams are perennial, but several appear to be ephemeral during seasonally dry periods. Because soil is shallow in the study area (Swanston 1967), bedrock was naturally exposed in 13.4 and $26.9 \%$ of the channel sections in OG1 and OG2 channels, respectively. Moreover, because of extensive landslide and debris flow scour and runout, the upper sections of LS and YA channels had 25-60\% exposed bedrock (Table 1).

\section{Methods}

\section{Field methods}

Representative channel reaches were intensively investigated during the period from June to August 1998. Stream gradient and cross-sectional profiles were surveyed using an engineer's level, stadia rod, and tapes. Stream elevation was measured at 5-m intervals and at each significant slope break. For example, the upper and lower boundaries of log steps and the front and back of sediment wedges were surveyed. Exposed bedrock length and its position in the channels were also measured. The wetted and bank-full
Fig. 1. Location of study sites in headwater streams of Maybeso Experimental Forest and the Harris River basin. Broken line shows watershed boundary. See Table 1 for definitions of the treatment codes.

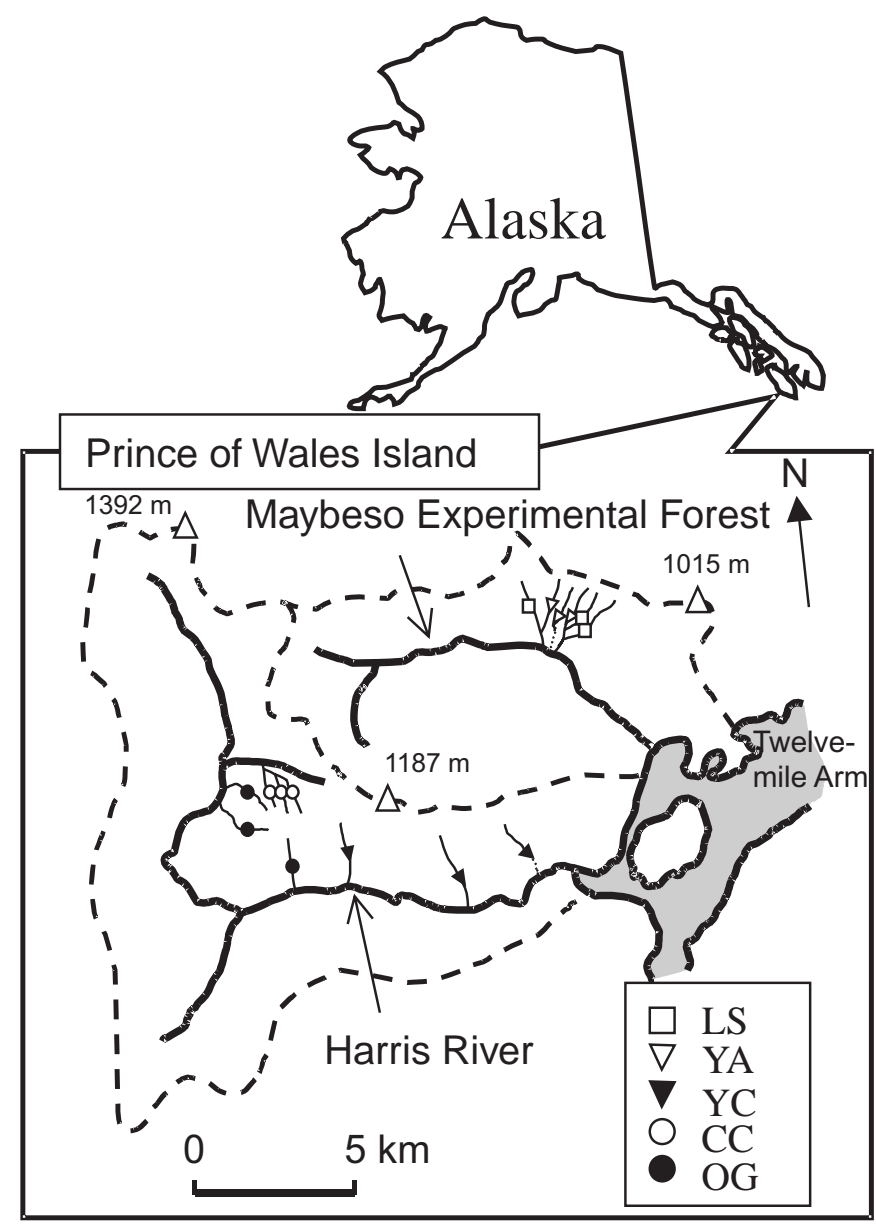

widths of streams were estimated every $5 \mathrm{~m}$. Bank-full width was defined by the presence of moss and rooted vegetation along the channel margins and the top of banks. Three cross sections in each stream were surveyed to describe valley and channel profiles. At the three cross sections, the median diameters of 100 pebbles in a $0.2 \times 0.2 \mathrm{~m}$ grid were measured to provide an indication of mobile streambed material (Wolman 1954). Large cobble and bolder components $>0.2 \mathrm{~m}$ were excluded because of their relative immobility except during landslide and debris flow events. Watershed area for each stream was calculated from topographic maps (U.S. Geological Survey, Craig C-3 and B-3; 1991) using a digital planimeter.

Organic debris in streams was divided into woody debris and fine organic debris (FOD). Woody debris was further classified into two categories: $(i)$ large woody debris (LWD), which were pieces $\geq 0.5 \mathrm{~m}$ in length and $\geq 0.1 \mathrm{~m}$ in diameter, and (ii) fine woody debris (FWD), which were pieces $\geq 0.5 \mathrm{~m}$ in length and $0.03-0.1 \mathrm{~m}$ in diameter. To quantify the distribution and accumulation of woody debris at each site, the following properties of LWD were measured: in-channel, bank-full, and total lengths; diameter; position; and orientation. In-channel length was measured for either a portion or the entire length of LWD pieces located within the wetted channel width that significantly dissipated flow energy and affected sediment transport. Bank-full length was defined as either a portion or the entire length of LWD pieces within bank-full width. Total length was measured for entire pieces of LWD including terrestrial portions. Diameter at the middle of each woody debris piece was recorded. Volume $\left(\mathrm{m}^{3}\right)$ of LWD $(V)$ was calculated as 
Table 1. Characteristics of the study sites.

\begin{tabular}{|c|c|c|c|c|c|c|c|}
\hline & $\begin{array}{l}\text { Drainage } \\
\text { area } \\
\left(\mathrm{km}^{2}\right)\end{array}$ & $\begin{array}{l}\text { Length of } \\
\text { studied } \\
\text { channel (m) }\end{array}$ & $\begin{array}{l}\text { Gradient } \\
(\%)^{a}\end{array}$ & $\begin{array}{l}\text { Bank-full } \\
\text { width }(\mathrm{m})^{a}\end{array}$ & $\begin{array}{l}\text { Bedrock } \\
(\%)\end{array}$ & $\begin{array}{l}D_{50} \\
(\mathrm{~mm})\end{array}$ & $\begin{array}{l}\text { Landslides } \\
\text { and debris } \\
\text { flows }\end{array}$ \\
\hline LS1, upper $^{b}$ & 0.21 & 340 & $40.3(11.0)$ & $1.2(0.6)$ & 26.7 & 30 & 1993, 1979 \\
\hline LS1, lower & & 400 & $9.9(5.8)$ & $2.6(1.5)$ & 0.0 & 25 & \\
\hline LS2, upper $^{b}$ & 0.27 & 150 & $31.0(12.3)$ & $1.6(0.4)$ & 40.7 & 31 & 1993 \\
\hline LS2, lower & & 250 & $13.7(6.0)$ & $1.8(0.6)$ & 0.0 & 30 & \\
\hline LS3, upper $^{b}$ & 0.35 & 300 & $31.7(11.5)$ & $2.8(1.3)$ & 59.8 & 43 & 1993 \\
\hline LS3, lower & & 350 & $9.4(8.1)$ & $3.7(1.3)$ & 0.0 & 29 & \\
\hline YA1, upper ${ }^{b}$ & 0.22 & 125 & $36.6(9.3)$ & $1.1(0.5)$ & 26.0 & 36 & 1961 \\
\hline YA1, lower & & 100 & $17.5(6.8)$ & $1.4(0.5)$ & 2.0 & 35 & \\
\hline YA2, upper ${ }^{b}$ & 0.14 & 225 & $42.7(9.1)$ & $0.9(0.3)$ & 38.0 & 40 & 1961 \\
\hline YA2, lower & & 125 & $18.6(7.1)$ & $0.9(0.3)$ & 0.0 & 27 & \\
\hline YA3, upper ${ }^{b}$ & 0.21 & 150 & $28.9(11.2)$ & $2.0(0.6)$ & 47.1 & 38 & 1979, 1961 \\
\hline YA3, lower & & 300 & $17.4(7.3)$ & $1.9(0.6)$ & 0.0 & 28 & \\
\hline YC1 & 0.24 & 300 & $23.8(5.7)$ & $1.2(0.4)$ & 0.0 & 28 & \\
\hline YC2 & 0.12 & 100 & $43.0(11.5)$ & $0.6(0.4)$ & 0.0 & 40 & \\
\hline YC3 & 0.26 & 250 & $25.8(7.3)$ & $1.9(1.0)$ & 21.9 & 33 & \\
\hline $\mathrm{CC} 1$, upper $^{c}$ & 0.20 & 200 & $44.4(6.4)$ & $0.9(0.4)$ & 0.0 & 48 & \\
\hline $\mathrm{CC} 1$, lower & & 190 & $25.5(8.2)$ & $1.0(0.4)$ & 0.1 & 30 & \\
\hline CC2, upper $^{c}$ & 0.20 & 130 & $45.9(6.2)$ & $0.9(0.5)$ & 0.1 & 40 & \\
\hline CC2, lower & & 150 & $32.5(12.7)$ & $0.9(0.4)$ & 0.0 & 19 & \\
\hline CC3 & 0.19 & 225 & $39.8(7.6)$ & $1.3(0.7)$ & 0.0 & 38 & \\
\hline OG1 & 0.19 & 150 & 40.9 (11.7) & $0.8(0.4)$ & 13.4 & 62 & \\
\hline OG2 & 0.22 & 150 & $45.0(8.7)$ & $1.6(1.1)$ & 26.9 & 50 & \\
\hline OG3 & 0.25 & 200 & $8.5(4.1)$ & $1.9(0.6)$ & 0.1 & 37 & \\
\hline
\end{tabular}

\footnotetext{
Note: LS, recent landslide (landslide or debris flows in 1979 and (or) 1993); YA, young alder riparian forest (logged from 1953 to 1957 and landslide or debris flows in 1961 and (or) 1979); YC, young conifer riparian forest (logged from 1959 to 1961); CC, clearcut (logged in 1995); OG, old-growth sites.

${ }^{a}$ Values are means with SDs given in parentheses.

${ }^{b}$ Sites are divided into scour or runout (upper section) and deposition (lower section) zones of landslides and debris flows.

${ }^{c}$ Sites are divided into upper and lower reaches at logging roads.
}

Fig. 2. Schematic view of headwater streams with and without landslide and debris flows. Sediment stored behind woody debris is distributed along stream channels in headwater streams without landslide and debris flows. The accumulation of sediment and woody debris occurred in the deposition zone after landslide and debris flows. The terminal end of deposition does not reach a main channel because of the wide and flat bottom of U-shaped glacial valley.

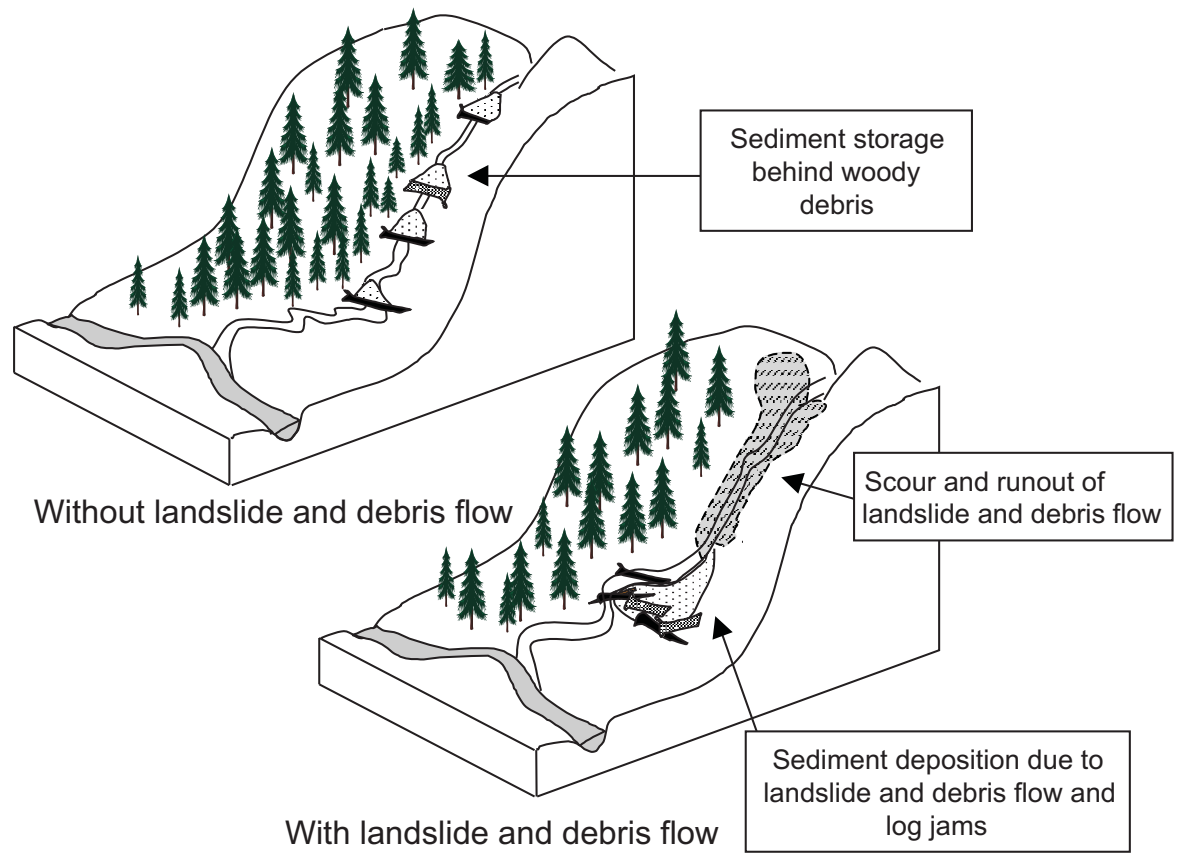


follows for the in-channel, bank-full, and total volume components of LWD:

$$
\text { [1] } \quad V=\pi\left(\frac{D}{2}\right)^{2} L
$$

where $D$ and $L$ are the mid-log diameters and appropriate lengths, respectively (Robison and Beschta 1990). Even though several studies applied a volume equation using end diameters of LWD pieces (Nakamura and Swanson 1993; Inoue and Nakano 1998), we used only median diameter as an approximation for estimating LWD volumes because of our small stream widths. All LWD pieces were classified as functional (interacting directly with streams), transitional (not directly interacting with streams but suspended just above streams and decomposed enough to interact with streams in the near future), and nonfunctional (no interaction with streams and (or) suspended well above channels). Orientation of LWD was measured in relation to a line parallel to the channel axis to determine the degree of interaction of LWD pieces with streams. Both left- $(+)$ and right-hand (-) orientations of LWD from 0 to $90^{\circ}$ were recorded in $\pm 5^{\circ}$ intervals. LWD recruitment in CC sites was divided into three types based on the period of recruitment: (i) recent recruitment (i.e., just after logging); (ii) during logging; and (iii) before logging. These groupings were based on field inspection of cutting edges and decay in woody debris. FWD was surveyed for channel position and number of pieces. Volumes of fine organic debris (FOD), such as accumulations of leaves, branches, and fine logging slash were categorized as small $\left(<0.01 \mathrm{~m}^{3}\right)$, medium $\left(0.01-0.1 \mathrm{~m}^{3}\right)$, and large $\left(\geq 0.1 \mathrm{~m}^{3}\right)$ volumes where FOD accumulations contributed to and (or) formed a sediment wedge.

Sediment storage behind woody debris and other obstructions (e.g., rock and bedrock) was measured in these headwater streams based on the geometry of the sediment wedge (width $(w)$, length of the wedge $\left(L_{w}\right)$, and mean depth at the front of the wedge $(d)$ ). Mean depth of the sediment wedge was measured using a sediment probe at several points. The cause of sediment deposition was categorized according to the formation elements of debris dam: LWD, FWD, FOD, rocks, and bedrock. The volume of sediment stored behind woody debris and other obstructions was computed based on a rectilinear pyramid:

[2] Sediment volume $=\frac{w L_{w} d}{3}$

The approximation of a pyramid-shaped wedge appears appropriate since the upstream end of stored sediment typically converges to a point in these small channels. Sediment storage ratio, determined as the volume of sediment behind woody debris divided by volume of all stored sediment, was assessed to estimate the relative contribution of woody debris for storing sediment.

\section{Statistical methods}

Three levels of hierarchical structure in statistical analysis were treatments, sites within treatments, and 20-m consecutive reaches within sites. Treatments (LS, YA, YC, CC, and OG) were fixed factors, while sites $(1,2$, and 3$)$ nested within each treatment were considered random factors. Thus, a mixed effect procedure was conducted to assess treatment effects (Neter et al. 1996). For these analyses, the lower (depositional) reaches of LS, YA, and CC channels were excluded. All 15 sites were divided into consecutive 20-m reaches to test the treatment effects on distribution and abundance of woody debris and sediment. At the scale of these 20-m reaches (about an order of magnitude greater than bank-full width), woody debris, sediment, and channel morphology are governed by relatively uniform hydrologic and geomorphic processes (Frissell et al. 1986). Because consecutive $20-\mathrm{m}$ reaches might be correlated with each other, repeated measurement effects were also incorporated in the statistical model.

The PROC MIXED procedure of SAS version 8 was used for analyzing the mixed-effects model (Littell et al. 1999). This procedure permits the inclusion of an unequal number of samples (i.e., $20-\mathrm{m}$ reaches) in the analysis. Number and volume of LWD (inchannel and total), number of FWD pieces, total volume of sediment, and volume of sediment stored behind woody debris were measured in each 20-m section. Channel gradient and bank-full width were related to the abundance, distribution, and in-stream function of woody debris (e.g., Bilby and Ward 1989). Thus, stream gradient and average bank-full width in the 20 -m reaches were used as covariate terms in the statistical models. If interaction terms such as treatment $\times$ stream gradient and treatment $\times$ bankfull width were significant in the mixed-effect analysis of covariance (ANCOVA), relationships among the dependent variables and stream gradient and bank-full width were assessed. If interaction terms were not significant, the mixed-effect analysis of covariance (ANCOVA), including treatment and two covariate effects (channel gradient and bank-full width), was conducted to assess treatment effects (Neter et al. 1996). In this case, the reduced model (i.e., without interaction terms) was compared with the full model based on AIC (Akaike information criterion) (Littell et al. 1999). Then, if treatment effects were significant, Bonferroni multiple comparisons were conducted to estimate the differences among treatments. The upper and lower sections in LS, YA, and CC sites were compared in a separate analysis. Lengths and diameters of LWD pieces in each treatment were statistically compared using the Wilcoxon rank sum test because the sizes of LWD pieces were strongly skewed. A significance level of $\alpha=0.05$ was used for all statistical analyses.

The mixed effect ANCOVA model using PROC MIXED procedure was also applied to analyze total sediment volume, volume of sediment stored behind woody debris, and sediment storage ratio in each 20-m reach. The number of LWD and FWD pieces, volume of LWD, estimated volume of FOD, stream gradient, and bank-full width were used as covariate terms in the full models.

It was also hypothesized that the different types of woody debris (LWD, FWD, and FOD) had different functions related to sediment storage among treatments. Thus, the sediment storage behind woody debris in each treatment was evaluated using a linear regression model to indicate the influence of stream conditions and woody debris characteristics. Significant independent variables in the full model (number of LWD and FWD pieces, volume of LWD, accumulation of FOD, stream gradient, and bank-full width) were selected by a stepwise procedure with $\mathrm{Cp}$ statistics (Neter et al. 1996). Null hypotheses that the coefficients of independent variables in the regression models are zero were tested at $\alpha=0.05$ level. All variables in this study were $\log (x+1)$ transformed to meet the assumption of normality and variance equality.

It was not possible to randomly sample streams in the study landscape, because treatments were dictated by external geomorphic factors (i.e., YA and LS), management effects (i.e., YC and CC), and natural conditions (i.e., OG). Thus, a fixed model of treatment effects was employed in this observational study. Additionally, there were limited numbers of certain stream types in the area. Also, the size and largely perennial nature of the required headwater systems as well as the need ensure a continuity of processes within each system limited our choices of steams in the landscape. Therefore, it was difficult to truly randomize sites within each treatment. Nevertheless, we rely on the robustness of statistical procedures to draw inferences related to treatments. We assume that the five stream types (treatments) cover the entire population of streams in the area. To further support our approach and inferences, we note that the landscape from which the streams were selected has basically the same lithology, soils, climate, hydrological processes, natural vegetation, and geomorphic processes (i.e., glaciation and deposi- 
Fig. 3. Distribution of diameter and length of large woody debris. L and U, upper and lower sections in LS, YA, and CC channels, respectively.

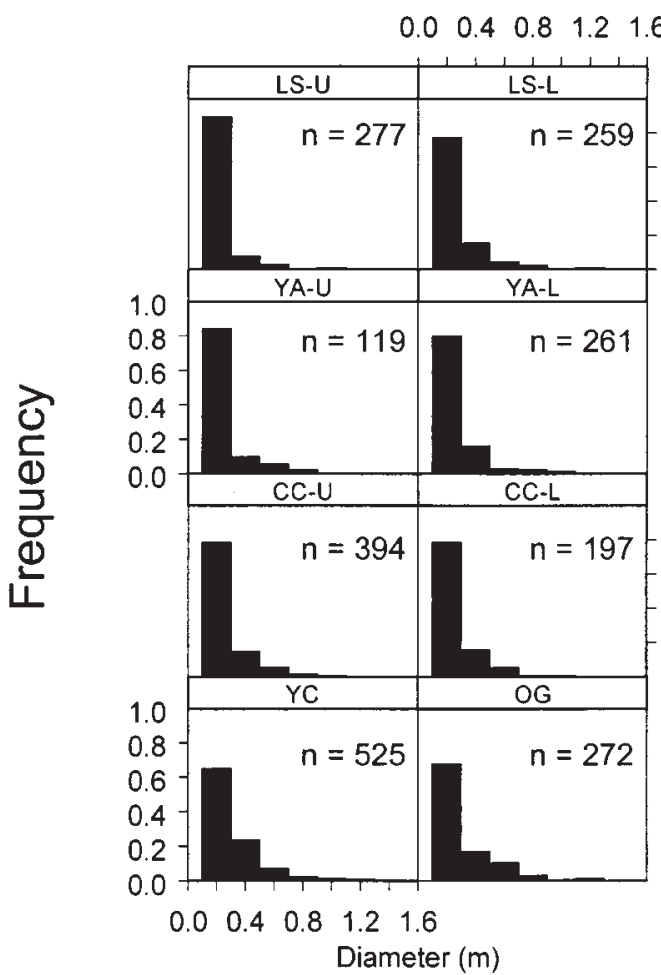

tion of till). In such humid terrain, aspect has little influence on hydrological processes. Thus, aside from the obvious "external" management and geomorphic perturbations that dictated our treatments, the "original" landscape and climate was uniform; this should minimize any confounding effect of the landscape (i.e., selection bias).

\section{Results and discussion}

\section{Characteristics of LWD pieces}

The distributions of diameter and length of LWD pieces were highly skewed to the smallest size classes in all streams (Fig. 3). Thus, median diameters and median lengths were used to represent central tendencies for each treatment. Median diameters of total LWD ranged from 0.15 to $0.24 \mathrm{~m}$ (Table 2). Relatively larger diameters were found in $\mathrm{YC}$ $(0.24 \mathrm{~m})$ and $\mathrm{OG}(0.20 \mathrm{~m})$ streams. Although other research in undisturbed streams of southeastern Alaska found that $10-25 \%$ of LWD pieces were $>0.6 \mathrm{~m}$ (Murphy and Koski 1989), we found that only 7.1 and $6.8 \%$ of LWD pieces were $>0.6 \mathrm{~m}$ in $\mathrm{OG}$ and $\mathrm{YC}$ headwater channels, respectively. In LS, YA, and CC channels, only $1.4-2.7 \%$ of LWD pieces were $>0.6 \mathrm{~m}$. According to the Wilcoxson rank sum test, diameters of LWD pieces in LS, YA, and CC were significantly smaller than those in the OG and YC channels.

Median lengths of entire LWD pieces ranged from 1.5 to $2.5 \mathrm{~m}$ in each treatment. There were few pieces of LWD $\geq 10 \mathrm{~m}$ in $\mathrm{LS}(3.4 \%)$, YC $(2.7 \%)$, and CC $(0.4 \%)$ streams compared with OG (6.6\%). Because of the regeneration and subsequent mortality of young alder stands, many alder logs were suspended above streams or interacted with streams without breakage. Thus, relatively large numbers of long LWD pieces $(\geq 10 \mathrm{~m})$ were found in YA $(7.5 \%)$. Lengths of LWD pieces in LS and CC were significantly shorter than in
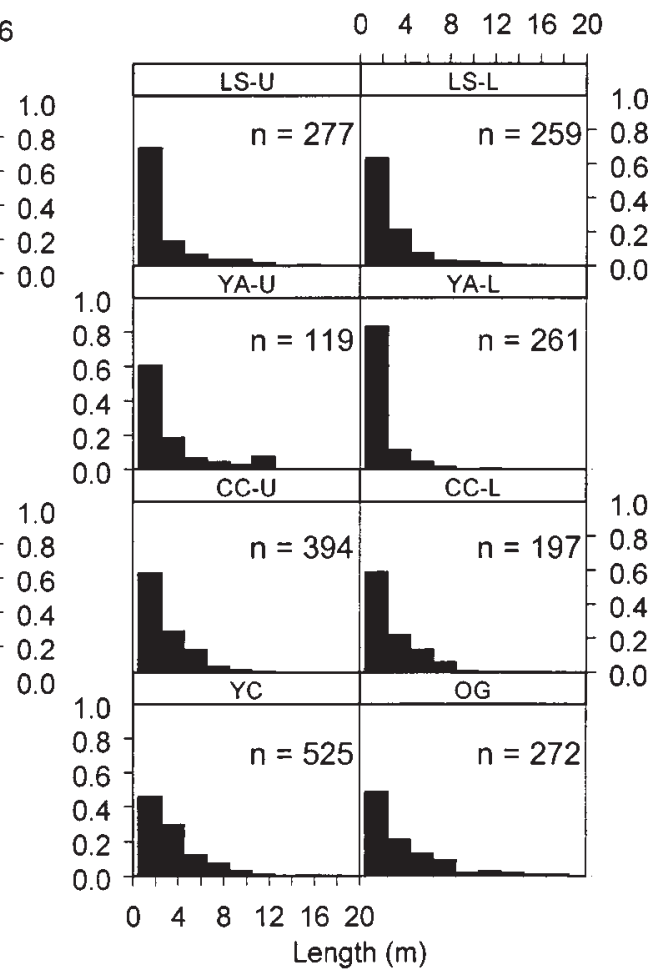

OG ( $p<0.001$ and $p=0.002)$. Lengths of LWD pieces in YA were slightly longer than in OG $(p=0.002)$.

LWD volumes per piece in all study streams ranged from 0.1 to $1.1 \mathrm{~m}^{3}$ and were small compared with other studies in the region that focused on lower gradient, wider streams in old-growth forests (Murphy and Koski 1989; Robison and Beschta 1990). Swanson et al. (1984) noted that the size of LWD was smaller in southeastern Alaska than in Oregon and Washington. Since large-diameter and valuable old-growth forests in southeastern Alaska have been logged during the past 50 years, the remaining old growth tends to have smaller diameters and lower productivity. Despite this limitation for selecting old-growth streams, our OG sites represent existing old-growth headwater channels in southeastern Alaska in which the recruitment and function of woody debris play important roles.

Both diameters and lengths of LWD pieces were significantly smaller in upper sections of LS compared with lower reaches. In contrast, lengths of LWD in lower YA channels were significantly shorter than in upper YA. The differences of LWD size with respect to upper and lower reaches of LS and YA might be related to the regeneration of young alder stands after landslides and debris flows and their subsequent mortality. There were no significant differences in LWD diameters between the lower and upper reaches of YA and CC. Lengths of LWD pieces in upper and lower CC sections were not significantly different.

The percentage of all LWD pieces that directly interacted with the 15 streams averaged $68.5 \%$ and ranged from 53.5 to $89.1 \%$. Sites without recognizable landslides and debris flows had a relatively constant percentage of LWD that directly interacted with channels; landslide channels had a higher variability of interactive LWD. Because of landslide deposition, a higher percentage (53-89\%) of interactive 
Table 2. The characteristics of woody debris.

\begin{tabular}{|c|c|c|c|c|c|c|c|c|}
\hline & \multicolumn{2}{|c|}{ No. of LWD/100 m } & $\begin{array}{l}\text { Diameter of } \\
\text { LWD }(\mathrm{m})^{a}\end{array}$ & $\begin{array}{l}\text { Median } \\
\text { diameter of } \\
\text { LWD }(\mathrm{m})\end{array}$ & $\begin{array}{l}\text { Total length } \\
\text { of LWD }(\mathrm{m})^{a}\end{array}$ & $\begin{array}{l}\text { Median total } \\
\text { length of } \\
\text { LWD }(\mathrm{m})\end{array}$ & $\begin{array}{l}\text { Total volume } \\
\text { per piece of } \\
\text { LWD }\left(\mathrm{m}^{3}\right)^{a}\end{array}$ & $\begin{array}{l}\text { No. of } \\
\text { FWD/100 m }\end{array}$ \\
\hline LS1, upper & 15 & 4 & $0.19(0.15)$ & 0.15 & $5.2(4.0)$ & 5.5 & $0.2(0.3)$ & 15 \\
\hline LS2, upper & 37 & 27 & $0.18(0.08)$ & 0.15 & $1.4(0.8)$ & 1.0 & $0.1(0.1)$ & 67 \\
\hline LS2, lower & 54 & 45 & $0.22(0.15)$ & 0.17 & $1.9(1.8)$ & 1.4 & $0.2(0.4)$ & 71 \\
\hline YA1, upper & 24 & 21 & $0.20(0.15)$ & 0.16 & $2.2(1.7)$ & 1.7 & $0.2(0.4)$ & 41 \\
\hline YA1, lower & 52 & 37 & $0.22(0.16)$ & 0.17 & $1.4(0.9)$ & 1.1 & $0.1(0.2)$ & 82 \\
\hline YA2, upper & 20 & 16 & $0.19(0.08)$ & 0.17 & $3.8(3.5)$ & 2.5 & $0.1(0.1)$ & 55 \\
\hline YA2, lower & 14 & 14 & $0.24(0.19)$ & 0.13 & $1.9(1.8)$ & 1.1 & $0.2(0.4)$ & 48 \\
\hline YA3, upper & 29 & 23 & $0.25(0.15)$ & 0.20 & $3.1(3.4)$ & 1.9 & $0.2(0.3)$ & 27 \\
\hline YA3, lower & 66 & 59 & $0.23(0.14)$ & 0.19 & $1.7(1.3)$ & 1.3 & $0.2(0.6)$ & 105 \\
\hline CC1, upper & 78 & 58 & $0.22(0.15)$ & 0.16 & $2.7(1.9)$ & 2.0 & $0.2(0.4)$ & 163 \\
\hline CC1, lower & 55 & 34 & $0.23(0.17)$ & 0.16 & $2.5(2.0)$ & 1.6 & $0.3(0.8)$ & 124 \\
\hline CC2, upper & 42 & 25 & $0.20(0.13)$ & 0.17 & $2.6(2.0)$ & 2.0 & $0.2(0.4)$ & 110 \\
\hline $\mathrm{CC} 2$, lower & 62 & 39 & $0.20(0.10)$ & 0.16 & 2.7 (1.9) & 2.0 & $0.1(0.2)$ & 99 \\
\hline $\mathrm{CC} 3$ & 82 & 65 & $0.23(0.15)$ & 0.17 & $1.6(0.9)$ & 2.0 & $0.2(0.4)$ & 151 \\
\hline OG1 & 31 & 21 & $0.24(0.13)$ & 0.20 & $4.0(3.8)$ & 2.5 & $0.3(0.7)$ & 124 \\
\hline OG2 & 41 & 24 & $0.37(0.26)$ & 0.26 & $4.6(4.1)$ & 2.7 & $1.1(2.5)$ & 143 \\
\hline OG3 & 52 & 33 & $0.25(0.19)$ & 0.19 & $3.1(2.5)$ & 2.2 & $0.4(1.1)$ & 150 \\
\hline
\end{tabular}

Note: See Table 1 for definitions of the treatment codes.

${ }^{a}$ Standard deviations are given in parentheses.

LWD was observed in the lower sections of LS and YA. About $50-70 \%$ of LWD was oriented from $0^{\circ}$ to $\pm 45^{\circ}$ with respect to the channel; however, no significant differences in orientation were found among the various treatments.

\section{Effects of timber harvesting on the abundance of LWD}

For all analyses related to treatment effects, the interactions between treatment $\times$ stream gradient and treatment $\times$ bank-full width were not significant; thus, treatment effects were assessed by the mixed-effect ANCOVA model (Table 3). Additionally, based on AIC, the reduced model (i.e., without interaction terms) had a better fit than the full model (Littell et al. 1996). The in-channel numbers of LWD pieces were significantly higher in $\mathrm{YC}$ and $\mathrm{CC}$ compared with numbers in OG, YA, and LS streams (Table 3). The total numbers of LWD in OG streams were significantly smaller that in $\mathrm{CC}$ but were not significantly different compared with YC. The abundance of LWD in both CC and YC channels increased because of the recruitment of LWD during past and recent logging activities. The number of LWD pieces was highest in the YC streams even though logging activities concluded three decades ago and woody debris has been gradually decomposing.

No significant differences in total and in-channel volumes of LWD were found among OG, CC, and YC streams (Table 3). However, total volume of LWD per $100 \mathrm{~m}$ in $\mathrm{YC}$ was twice that in OG. Total volume of LWD per $100 \mathrm{~m}$ associated with CC channels was half that in OG channels; however, the majority of this volume in OG systems was outside the bank-full area. The higher numbers and volumes of
LWD in YC streams (mean total LWD pieces 82.7 and inchannel 45.0 pieces $/ 100 \mathrm{~m}$ ) are attributed to large inputs from logging in the early 1960s. In some sections of YC, the stream flowed under "tunnels" of LWD even though much rotten wood was evident. Tree falling and yarding techniques affect debris recruitment into headwater streams, and LWD levels can vary in managed forested streams (Froehlich 1973). Thus, past and recent logging activities appear to affect the distribution and abundance of LWD in headwater streams. The logging road through the $\mathrm{CC}$ channels did not significantly alter the abundance and distribution of woody debris below the road.

Although the numbers of LWD pieces in both $\mathrm{CC}$ and YC streams increased because of logging, the sizes and volumes of LWD in CC and YC differ (Fig. 4, Table 2). During the past 50 years, the amount and size of logging residue in harvested areas has changed with changing timber utilization, stand conditions, and logging and transportation techniques (Harris and Farr 1974). The standard for timber utilization has improved because of a variety of market conditions and upgrades in timber technology and industry. Before pulpmills were established in southeastern Alaska in 1953, only high-quality Sitka spruce and western hemlock were merchantable. In contrast, much low-quality timber has value in the present market. Although western redcedar and yellow-cedar (Chamaecyparis nootkatensis (D. Don) Spach.) have the highest value today, cedars were unused during 1950s. When loggers encountered cedars, they were normally cut and left in the woods (Harris and Farr 1974). Such practices led to abundant accumulations of large cedar in YC 
Table 3. Summary of mixed effect ANCOVA on the number and volume of woody debris in upper sections.

\begin{tabular}{|c|c|c|c|c|c|}
\hline & & Treatment & $\begin{array}{l}\text { Stream } \\
\text { gradient }\end{array}$ & $\begin{array}{l}\text { Bank-full } \\
\text { width }\end{array}$ & Multiple comparisons and means ${ }^{a}$ \\
\hline No. of in-channel LWD/20 m & $F$ & 4.99 & 5.32 & 0.01 & LS (3.6), YA (4.0), OG (5.1) $<$ YC (9.3), CC (10.9) \\
\hline \multirow[t]{2}{*}{ Total no. of LWD/20 m } & $F$ & 4.35 & 6.79 & 1.44 & $\begin{array}{l}\text { YA }(5.0), \text { LS }(6.8) \ll \text { CC }(14.4), \text { YC }(16.1) \\
\text { OG }(8.3)<<C C\end{array}$ \\
\hline & $p$ & 0.028 & 0.012 & 0.23 & \\
\hline In-channel volume of LWD $\left(\mathrm{m}^{3} / 20 \mathrm{~m}\right)$ & $p$ & 0.104 & 0.886 & 0.845 & \\
\hline \multirow[t]{2}{*}{ Total volume of LWD $\left(\mathrm{m}^{3} / 20 \mathrm{~m}\right)$} & $F$ & 7.27 & 0.66 & 1.36 & $\begin{array}{l}\mathrm{LS}(0.6) \ll \mathrm{CC}(0.27), \mathrm{OG}(5.8), \mathrm{YC}(8.2) \\
\mathrm{YA}(0.8) \ll<\mathrm{OG}, \mathrm{YC}\end{array}$ \\
\hline & $p$ & 0.005 & 0.419 & 0.419 & \\
\hline
\end{tabular}

\footnotetext{
Note: Multiple comparisons with Bonferroni method were conducted at the 0.05 of confidence level. Treatment $\times$ channel gradient and treatment $\times$ bank-full width were not significant. See Table 1 for definitions of the treatment codes.

${ }^{a}$ The order in percentiles from left to right shows the relative abundance (smaller abundance in left side). Values in parentheses are mean numbers. Treatments separated by $\ll$ symbols are significantly different.
}

Fig. 4. Volumes of LWD in and around streams. In channel: the volume of LWD located within the wetted channel width that significantly affects flow dissipation and sediment transport. Bank-full: the volume of LWD located within the bank-full width, which was defined by the absence of vegetation. Outside: the volume of the terrestrial portion of LWD located outside of the bank-full width. See Table 1 for definitions of the treatment codes.

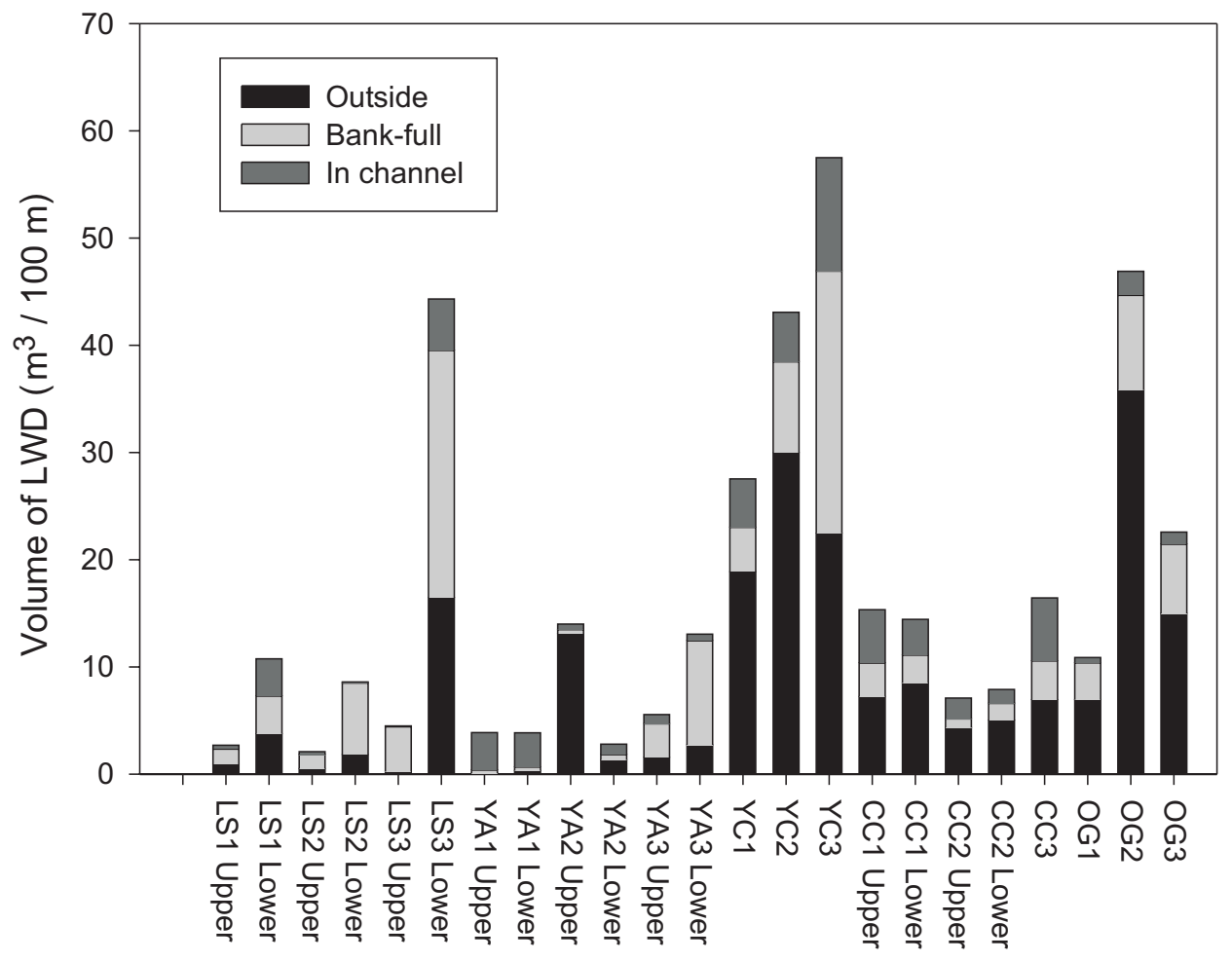

channels. In addition, logging and timber transportation systems are usually designed for the largest class of logs. Thus, such systems may not be suitable for handling smaller logs and broken pieces. With such technical limitations, evenaged stands are more preferable for cutting, and less logging residue is generated compared with harvesting mixed-aged stands (Harris and Farr 1974). By evaluating stump diame- ters, it is evident that trees harvested near YC channels in the 1950s and early 1960s were much larger and of greater age diversity than trees cut in 1995 at CC sites.

While we observed increases in the numbers of pieces of LWD (in channel and total) in YC and CC due to timber harvesting, Murphy et al. (1986) found 54\% less LWD pieces in clear-cut streams compared with old-growth chan- 
nels in larger, low-gradient streams of southeastern Alaska. Lower numbers of LWD pieces were also found in logged streams in southwestern Washington (Bilby and Ward 1991). Ralph et al. (1994) found no significant differences in the number of LWD pieces among unharvested, moderately harvested, and intensively harvested streams in western Washington. In contrast, Froehlich (1973) reported that logging resulted in a 2- to 10-fold higher recruitment of woody debris (i.e., slash) compared with natural debris in steep headwater streams of Oregon.

The conflicting findings from these studies and our research can be attributed to $(i)$ changing management guidelines related to logging activities, including buffer strip leave areas, and (ii) modification of recruitment and distribution of woody debris after and during logging, including the time lag of recruitment. Management regulations for woody debris and riparian buffers have changed dramatically because of concerns related to fish and wildlife habitat. Because of forest-practices codes and rules that have been established and upgraded in the Pacific Northwest during the past few decades, damage to fish-bearing streams has been reduced and very large accumulations of logging-related woody debris have been partly removed in larger streams (Bisson et al. 1987). Thus, under current forest practices, such accumulations in fish-bearing streams are less frequent compared with earlier logging operations. Riparian buffer strips are designed to minimize impacts of timber harvesting on water temperature, bank erosion, and woody debris loading. Without buffer strips, LWD recruitment from riparian stands would be drastically reduced after logging. If continual inputs of woody debris to streams are not sustained, existing debris will wash away and decay, thus reducing the numbers of pieces. In contrast, logging residues and blowdown from riparian stands can increase the numbers of LWD pieces after logging (Froehlich 1973; Bryant 1980). Despite such considerations in lower gradient streams, steep and small headwater streams have not been carefully managed for long-term recruitment and function of woody debris. From 36 to $60 \%$ of LWD in our CC channels was recruited during and just after logging. Volume of LWD recruited during logging and just after logging activities ranged from 2.6 to $7.0 \mathrm{~m}^{3} / 100 \mathrm{~m}$ in the three $\mathrm{CC}$ channels. Although the amount of LWD added by logging activities was relatively small compared with levels reported by Froehlich (1973), these inputs are significant in small headwater streams. Moreover, evidence from nearby streams suggests that, in the absence of landslides and debris flows, woody debris may persist at least 50-100 years, because flow in these small headwater channels is too small to transport large amounts of woody debris.

\section{Abundance of fine woody debris}

The number of FWD pieces in LS and YA streams was significantly smaller compared with all other systems (Table 3), while the difference between OG and YA $(p=0.065)$ was not significant. However, Sidle (1986) found that organic and small woody debris inputs were about twice as high as in old-growth streams compared with young alder streams in southeastern Alaska. Despite the significant regeneration of alder riparian stands in YA sites, numbers of FWD in LS and YA channels were not significantly differ- ent. The potential explanations of this result are (i) deciduous FWD is broken and decomposed more rapidly compared with coniferous FWD (Harmon et al. 1986), and (ii) fallen branches and stems from alder riparian stands of YA sites are smaller than FWD category. Thus, differences in abundance of FWD between YA and LS were not statistically apparent.

There is no significant difference in the numbers of FWD among CC, YC, and OG channels. However, Bilby and Ward (1991) observed that more fine organic debris occurred in old-growth streams than in clear-cut and young-growth streams in Washington. In the Pacific Northwest, coniferous woody materials from old-growth forests have much slower decay rates than hardwood materials (Harmon et al. 1986). Thus, woody materials from coniferous old-growth stands accumulate and persist in stream channels.

Although the numbers of FWD pieces were not significantly different between OG and CC (Table 3), the recruitment of FWD in CC channels was largely related to logging activity (slash and small branches), while FWD in OG channels was attributed to natural inputs. Froehlich (1973) found logging slash to be a primary factor affecting FWD recruitment in headwater streams. A significant increase in FWD loading after clear-cutting was also found in low-gradient streams in southeastern Alaska and western Oregon (Swanson et al. 1984). Large numbers of FWD also occurred in YC, even though much of this material was decayed and rotted. An old timber landing located just below the lowest reaches of YC3 contributed extensive FWD (400 pieces/100 m). Numbers of FWD pieces in the upper and lower reaches of LS and YA varied widely; however, relatively small numbers of FWD were found in the upper reaches (Table 2).

\section{Effects of landslides and debris flows on woody debris accumulations and distributions}

The effects of landslides and debris flows on LWD can be assessed by comparing the two channels affected by these disturbances (LS and YA) with OG channels. Both total and in-channel numbers of LWD were not significantly different among OG, YA, and LS channels (Table 3). Although the landslides and debris flows transported LWD in the upper section of LS, some residue was found in and around stream channels. In YA, woody debris was also introduced from riparian stands in the intervening years after landslide activities. Thus, the numbers of LWD pieces among OG, YA, and LS were not statistically different. However, in-channel volumes of LWD in LS and YA channels were significantly smaller than volumes in OG streams because individual LWD pieces were relatively large and mature in OG systems (Table 3).

The number of LWD pieces in upper LS1 reach (15 total and 4 in-channel LWD pieces) was extremely low, because this channel experienced two major landslide and debris flow events (1973 and 1993) compared with one event in 1993 in the other LS channels (Table 2, Fig. 4). Although two landslides and debris flows in 1961 and 1973 affected upper YA3, LWD levels were similar in all YA channels. These results indicate the importance of succession and recruitment of riparian alder into scour and runout zones of YA streams.

For both LS and YA, assessment of all organic components between upper and lower reaches yielded a significant 
treatment $\times$ channel gradient interaction. However, the average number of total (58.0 pieces) and in-channel (40.0 pieces) LWD per $100 \mathrm{~m}$ in the lower LS were relatively larger than numbers in the upper LS (36.3 and 19.3 pieces, respectively). Similar tendencies were also found in YA channels (Table 2). The accumulation of LWD in the depositional zones of landslides and debris flows is common (Fig. 2). Johnson et al. (2000) indicated that the amount of LWD accumulation in the deposition zones (i.e., debris fans) was largest in old-growth channels followed by secondgrowth and clear-cut channels. Because landslides in YA channels occurred 5-9 years after clear-cutting, only logging residue and small-diameter standing trees were transported. In contrast, LWD transported by recent landslides and debris flows was associated with second-growth conifer riparian stands with mean diameters of $0.15-0.25 \mathrm{~m}$. Therefore, much larger volumes of LWD were transported to lower LS reaches compared with lower YA reaches.

Stream gradient significantly influenced both in-channel and total numbers of LWD pieces (Table 3); gradient effects on numbers of FWD pieces were barely insignificant $(p=$ 0.065 ). Correlations between numbers of LWD pieces (and also FWD) and channel gradient were conducted for all treatments including lower reaches of LS, YA, and CC. Correlations for LWD $(r=-0.53, p<0.001)$ and FWD $(r=$ $-0.61, p<0.001)$ were significant only in upper LS. These negative correlations indicate that the number of woody debris pieces decreased with increasing stream gradient.

Numbers and volumes of LWD and FWD pieces were not significantly related to bank-full width (Table 3 ). In contrast with our results, Bilby and Ward (1989) found a negative correlation between channel bank-full width and LWD frequency in larger, lower gradient streams.

Our findings show that only landslides and debris flows modify the distribution of LWD and FWD with respect to gradient in headwater streams. In wider and lower gradient streams, woody debris distribution might be controlled by the size of woody debris, flow regimes, bank-full width, and channel sinuosity (Bilby and Ward 1989; Robison and Beschta 1990; Nakamura and Swanson 1994). In such larger systems, stream size and flow regimes must be sufficient to transport LWD and FWD. However, bank-full widths and basin areas of headwater streams are generally too small to transport significant amounts of woody debris compared with fluvial processes in lower gradient channels. The distribution of woody debris in small streams is more likely affected by random factors such as bank erosion, tree mortality, windthrow, and logging slash (Berg et al. 1998). However, dynamic colluvial processes, such as landslides and debris flows, and intrinsic channel properties (i.e., gradient and channel smoothness) influence the distribution of woody debris in LS channels. Landslide channels typically have lower roughness than other systems; thus, gradient breaks more strongly influence LWD and FWD accumulation in LS channels compared with channels with greater lateral and longitudinal roughness complexity.

\section{The amount of sediment accumulation}

Differences in sediment storage among the various stream types appeared to be masked by high variability among sites, especially in LS and CC channels (Fig. 5). Although not sig- nificantly different (Table 4), mean total volumes of sediment were considerably higher in LS and YA (5.35 and $4.75 \mathrm{~m}^{3} / 100 \mathrm{~m}$, respectively) than in $\mathrm{YC}$ and $\mathrm{OG}$ channels (1.6 and $1.3 \mathrm{~m}^{3} / 100 \mathrm{~m}$, respectively). Because of landslides and debris flows as well as subsequent sediment movement from hillslopes to channels, headwater streams in LS and YA were relatively sediment rich. Active small bank failures contributed sediment transport in CC2.

The volume of sediment stored behind woody debris in YA channels was significantly larger compared with OG, YC, and CC channels (Table 4). This increased storage in YA channels is attributed to the abundance of both sediment and woody debris resulting from past mass movements and subsequence riparian generation. For instance, in upper LS reaches, woody debris was a limiting factor, because it was largely transported downstream by landslides and debris flows while sediment remained abundant. In contrast, sedimentlimited conditions and lower transport capacities induce smaller sediment accumulations behind woody debris (Berg et al. 1998). Rain splash, overland flow, shallow bank failures, and freeze-thaw activity are the major erosive factors on disturbed slopes that recharge sediment into streams in LS channels. In the lower reaches of landslide channels, both sediment and woody debris are very abundant. Consequently, the role of woody debris in headwater streams changes depending on the "limiting" conditions of sediment and woody debris.

The sediment storage ratio in LS channels was significantly smaller than in other channels (Table 4). Riparian regeneration and recruitment of woody debris after landslides in YA significantly increased the sediment storage capacity of the channel. Although more sediment was generally observed in sites that were affected by landslides, a lower percentage of sediment in the channel was stored behind woody debris in LS streams. However, $>79 \%$ of total sediment was stored behind woody debris in YC, CC, and OG channels (Table 4, Fig. 5). Similarly, $84 \%$ of sediment was stored behind logs, organic debris, roots, and stumps in steep streams in Idaho (Megahan 1982). In our study, FWD and FOD generally contributed less to sediment storage than LWD, but the amount of sediment stored behind FWD or FOD was the highest $(28.7 \%)$ in OG channels (Fig. 5). Total volume of sediment and sediment storage ratio between upper and lower sections of LS, YA, and CC were not significantly different. Out of the 702 LWD pieces that contributed to sediment storage, $53.7 \%$ were oriented perpendicular $\left( \pm 45^{\circ}\right)$ to the channels. However, only $37.9 \%$ of all LWD pieces were oriented perpendicular $\left( \pm 45^{\circ}\right)$ to channels. Thus, orientations that are nearly perpendicular highly influence sediment storage in all treatments.

\section{Factors of sediment storage in headwater streams}

Numbers of both LWD and FWD pieces significantly contributed to the volume of sediment stored behind woody debris (Table 4). Thus, a regression analysis was conducted for each treatment to predict volume of sediment stored behind woody debris using stream gradient, bank-full width, volume of LWD, number of LWD and FWD, and the accumulation of FOD as independent variables. The site variables were pooled in treatments to conduct the regression analysis. Multiple $R^{2}$ values ranged from 0.20 to 0.61 and from 0.23 to 
Fig. 5. Volumes of sediment behind woody debris and the other obstructions. LWD: large woody debris formed sediment storage. FWD-FOD: fine woody debris and fine organic debris formed sediment storage. Others: rock and bedrock formed sediment storage. See Table 1 for definitions of the treatment codes.

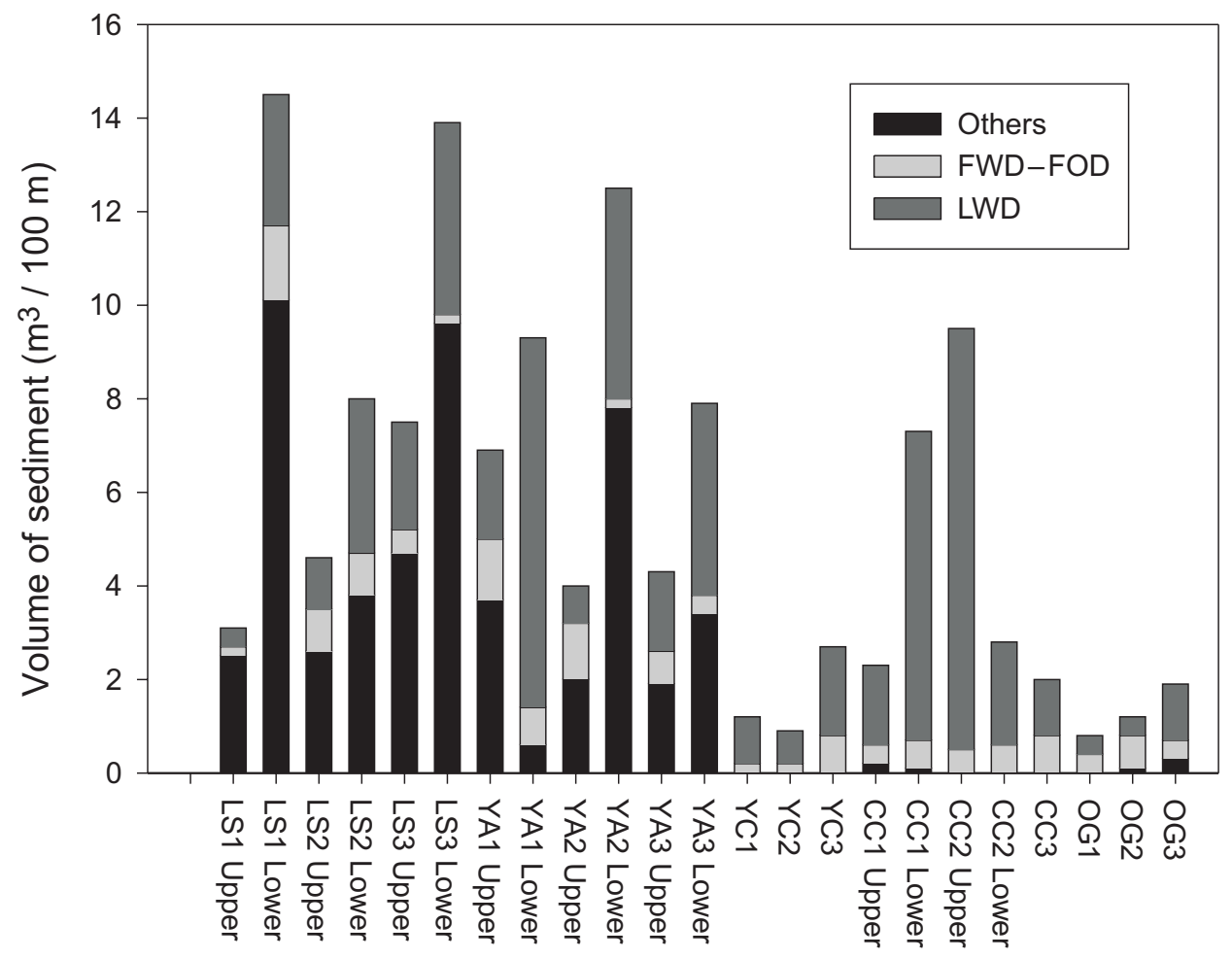

Table 4. Summary of mixed-effect ANCOVA for sediment accumulation and sediment storage behind woody debris in upper sections.

\begin{tabular}{|c|c|c|c|c|c|c|c|c|c|}
\hline & & Treatment & $\begin{array}{l}\text { Stream } \\
\text { gradient }\end{array}$ & $\begin{array}{l}\text { Bank-full } \\
\text { width }\end{array}$ & $\begin{array}{l}\text { No. of } \\
\text { LWD }\end{array}$ & $\begin{array}{l}\text { In-channel } \\
\text { volume of } \\
\text { LWD }\end{array}$ & $\begin{array}{l}\text { No. } \\
\text { of } \\
\text { FWD }\end{array}$ & FOD & Multiple comparison and mean ${ }^{a}$ \\
\hline $\begin{array}{l}\text { Volume of total } \\
\text { sediment }\left(\mathrm{m}^{3} / 20 \mathrm{~m}\right)\end{array}$ & $p$ & 0.085 & 0.551 & 0.130 & 0.631 & 0.485 & 0.366 & & \\
\hline \multirow[t]{2}{*}{$\begin{array}{l}\text { Volume of sediment } \\
\text { storage behind } \\
\text { woody debris }\left(\mathrm{m}^{3} /\right. \\
20 \mathrm{~m})\end{array}$} & $F$ & 4.04 & 0.07 & 0.91 & 13.0 & 2.12 & 12.9 & 0.54 & $\begin{array}{l}(\mathrm{OG}, \mathrm{YC}, \mathrm{CC}) \ll \mathrm{YA} \\
(0.24,0.37,0.49) \ll 0.60 \\
\text { No differences in LS }\end{array}$ \\
\hline & $p$ & 0.009 & 0.796 & 0.344 & 0.001 & 0.149 & 0.001 & 0.462 & \\
\hline $\begin{array}{l}\text { Sediment storage ratio } \\
\text { per } 20 \mathrm{~m}\end{array}$ & $F$ & 6.96 & 0.10 & 2.11 & 4.28 & 4.03 & 0.01 & & $\begin{array}{l}\mathrm{LS} \ll(\mathrm{YA}, \mathrm{OG}, \mathrm{YC}, \mathrm{CC}) \\
0.22 \ll(0.55,0.79,0.82,0.88)\end{array}$ \\
\hline
\end{tabular}

Note: Multiple comparisons with Bonferroni method were conducted at the 0.05 of confidence level. No interaction term was significant. Treatments separated by $\ll$ symbols are significantly different. See Table 1 for definitions of the treatment codes.

${ }^{a}$ Values in parentheses are means.

0.74 in upper and lower reaches, respectively (Table 5). Multicolinearity occurred only between numbers of LWD pieces and volumes of LWD in the regression model for lower LS reaches $(r=0.74$ and $p<0.001)$. In all treatments, stream gradient did not significantly influence the volume of sediment stored behind woody debris.

In OG channels, numbers of LWD and FWD pieces equally accounted for the volume of sediment stored behind woody debris (Table 5). The numbers of FWD pieces were significantly related to sediment storage in recent clear-cut sites (CC), while LWD numbers contributed strongly to sediment storage in YC. Recent logging slash provided initial sediment storage sites in CC channels. Because the stability of logging slash largely depends on channel bank-full width (Millard 2000), logging residue in narrow CC channels is relatively stable. After decomposition of these woody materials, sediment accumulations may gradually shift to LWD jams. In upper LS channels, numbers and volumes of LWD accounted for the bulk of sediment storage (Table 5). FWD clearly provided sites for sediment storage, whereas FOD 
Table 5. Summary of stepwise regression analyses to predict volume of sediment stored behind woody debris (SW).

\begin{tabular}{llrrrr}
\hline Treatment & Equation & $R^{2}$ & $n$ & $F$ & $p$ \\
\hline Upper reach & & & & & \\
LS & $\mathrm{SW}=0.79(\mathrm{LWD})+2.20($ volume $)-2.4446$ & 0.56 & 26 & 15.22 & $<0.001$ \\
YA & $\mathrm{SW}=0.67(\mathrm{FWD})-0.68(\mathrm{FOD})-0.83$ & 0.40 & 23 & 6.9 & 0.005 \\
YC & $\mathrm{SW}=0.27(\mathrm{LWD})-0.08$ & 0.32 & 31 & 14.4 & $<0.001$ \\
$\mathrm{CC}$ & $\mathrm{SW}=0.19(\mathrm{FWD})+0.03$ & 0.20 & 26 & 6.1 & 0.021 \\
OG & $\mathrm{SW}=0.10(\mathrm{LWD})+0.10(\mathrm{FWD})-0.10$ & 0.61 & 23 & 16.6 & $<0.001$ \\
Lower reach & & & & & \\
LS & $\mathrm{SW}=0.20(\mathrm{LWD})+0.56($ volume $)+0.13(\mathrm{FOD})+0.03$ & 0.74 & 68 & 62.5 & $<0.001$ \\
YA & $\mathrm{SW}=1.24($ volume $)-0.51($ width $)+0.74$ & 0.46 & 48 & 19.9 & $<0.001$ \\
CC & $\mathrm{SW}=0.28($ FWD $)-0.18$ & 0.23 & 30 & 8.9 & $<0.006$ \\
\hline
\end{tabular}

Note: Relationship between the volume of sediment behind woody debris (SW) and the other variables (BW, bank-full width; S, slope; LWD, no. of LWD; FWD, no. of FWD; volume, volume of LWD; FOD, accumulation of FOD) are selected using a stepwise procedure with Cp statistics. All variables were transformed using $\log (x+1)$ prior to regression analysis. The null hypotheses $\left(\mathrm{H}_{0}\right)$ is that the coefficients of variables are equal to 0 , are all rejected at 0.05 level except intercepts. See Table 1 for definitions of the treatment codes.

was inversely correlated to sediment storage in upper YA channels (Table 5). Large accumulations of FOD behind woody debris dams in steep channels may occupy storage space and actually reduce the levels of sediment accumulation. Because of the recolonization of alder riparian stands after landslides and the interaction of these woody materials with stream channels, FWD contributed more to sediment storage in YA than in LS streams. Although Bilby and Ward (1989) found that FWD was more common in smaller streams, differences in riparian stand structure, such as between LS and YA, also influence the distribution and abundance of FWD. In the lower reaches of LS and YA, volume of LWD was significantly correlated to sediment storage (Table 5). In addition, with increasing numbers of LWD pieces and accumulations of FOD, sedimentation behind woody debris increases in the lower LS channels.

Our study indicates that different characteristics of woody debris accounted for sediment storage in the upper and lower sections of streams affected by landslides and debris flows. In the lower sections of LS and YA channels, LWD jams are common because of deposition of landslide or debris flow material. Thus, the volume of jams may modify the spatial distribution of sediment deposition. Bilby and Ward (1989) found that surface area of sediment deposition was significantly associated with the volume of woody debris in wider, low-gradient forest streams in Washington. Lower gradient reaches have larger volumes of LWD pieces and jams and, thus, greater storage capacity behind LWD. On the other hand, high-gradient headwater streams have limited storage space for sediment. Thus, higher numbers of LWD and FWD pieces (i.e., multiple dams) are more important for greater sediment storage in headwater streams (Fig. 2). At the same time, some woody debris and sediment accumulations contribute to the formation of step structures in headwater channels. Such steps typically function to dissipate stream energy (Heede 1981). Size, interval, and stability of stepped-bed structures may critically affect sediment budgets and routing processes in headwater streams. The accumulation of sediment was controlled by different aspects of LWD in lower and upper reaches of landslide-affected channels as well as different types of woody debris resulting from disturbances (logging activities and landslides and debris flows) and the recovery phase after such disturbances. Conse- quently, the dynamics of sediment in headwater streams might be greatly affected by the recruitment of woody debris due to logging and related disturbances.

\section{Summary and conclusions}

During the past decade, low-gradient, fish-bearing streams in the Pacific Northwest have been managed to minimize the impacts of timber harvesting and other land uses on ecological and hydrological conditions of streams (Naiman et al. 2000). However, little attention has focused on regulating management activities around headwater streams, except for landslide and debris flow hazard mitigation. This may be attributed to the lack of understanding of the complete interactions between woody debris and sediment in headwater streams. Thus, the dynamics of headwater streams and their impacts on downstream resources are poorly understood, even though the headwater streams are primary sources of organic materials, nutrients, and sediments. Moreover, headwater streams often flow directly through timber harvest units. We found that timber harvesting and related landslides and debris flows affected the distribution and accumulation of woody debris and related sediment accumulation in headwater streams (Fig. 6). These effects are summarized as (i) inputs of logging slash and unmerchantable logs significantly increase the abundance of in-channel woody debris; (ii) in the absence of landslides or debris flows, these woody materials remain in the channel 50-100 years after logging; (iii) relatively smaller woody debris initially stores sediment; (iv) when landslides and debris flows occur 3-15 years after logging because of intensive rain and weakening of root strength (Sidle et al. 1985), woody debris is evacuated from headwater streams and deposited in downstream reaches; (v) although less woody debris remains in the scour zone, woody debris pieces and jams contribute to sediment storage in both the scour and deposition zones of landslide and debris flow channels; (vi) red alder stands actively recolonize riparian zones of headwater streams for 20-50 years after mass movement and recruit woody debris and organic materials, which in turn provide sediment storage sites; and (vii) subsequent sediment movement after landslides and debris flows is affected by residual woody debris and newly introduced debris. 
Fig. 6. Flow chart of woody debris and sediment accumulation in headwater streams. Examination of five management and disturbance regimes in this study (OG, CC, YC, YA, and LS) shows the changes of recruitment of woody debris and sediment storage in headwater streams along the time axis. Solid rectangles show the major recruitment modes of woody debris in each treatment. Rectangles with broken lines show types of sediment movement. Such changes due to management and disturbance are typically seen in landscape of southeast Alaska.

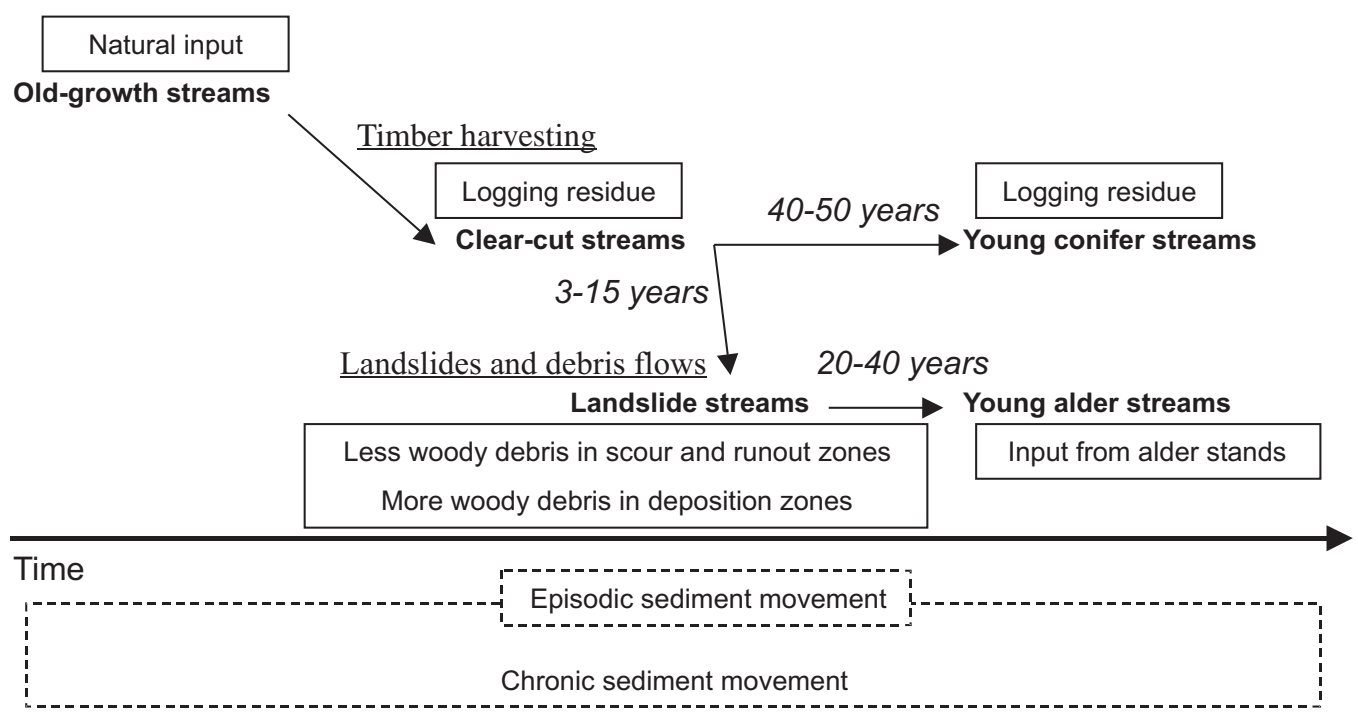

The disturbance regime, both natural and management related, significantly affected headwater ecosystems. Three aspects of disturbances appear to be important for understanding the functions of headwater streams: (i) logging slash; (ii) landslides and debris flows; and (iii) regeneration of riparian stands after logging and mass movement. Such conditional changes with time affect abundance and distribution of LWD, FWD, and sediment (Fig. 6). Moreover, these modifications determine the in-stream function of LWD and FWD, particularly related to sediment storage. Thus, the dynamics of sediment movement as well as stream channel geomorphology in headwater streams may relate to such management or disturbance regimes through time and space. Both episodic and chronic events are important for understanding the dynamics of headwater streams and to evaluate downstream impacts.

Forest practices in and around headwater streams are inconsistently regulated, and management is based on very limited scientific knowledge. For instance, steep headwater streams without salmonids do not typically require riparian buffer zones. Even when riparian buffer strips are left, the relatively narrow riparian corridor may be highly susceptible to windthrow. Wide riparian buffers in headwater systems will reduce the amount of timber available for harvest. To effectively manage headwater streams, information on geomorphic processes, hydrology, and riparian vegetation dynamics needs to be systematically integrated.

\section{Acknowledgements}

Support for this research was provided by the USDA Forest Service, Pacific Northwest Research Station and the University of British Columbia. We thank Brittany Graham, Adam Herren, Heather Hodgm, Karen McCartney, Katherine McGee, Dave Allan, and most notably Russell Smith for their assistance with fieldwork. We appreciate the advice of John Richardson, Forest Science Department, University of
British Columbia, on statistical procedures and interpretations. We also thank Patti Krosse and Adelaide Johnson, USDA Forest Service, for providing soil and landslide data. The support of the following persons during this study is greatly appreciated: Brenda Wright, Jack Piccolo, Scott Alexander, Duke Busch, Shully Millstein, and Osvaldo Hernandez. Appreciation is extended to the anonymous reviewers and Associate Editor for their helpful comments.

\section{References}

Berg, N., Carlson, A, and Azuma, D. 1998. Function and dynamics of woody debris in stream reaches in the central Sierra Nevada California. Can. J. Fish. Aquat. Sci. 55: 1807-1820.

Bilby, R.E., and Ward, J.W. 1989. Change in characteristics and function of woody debris with increasing size of stream in western Washington. Trans. Am. Fish. Soc. 118: 368-378.

Bilby, R.E., and Ward, J.W. 1991. Characteristics and function of large woody debris in streams draining old-growth, clear-cut, and second-growth forests in southwestern Washington. Can. J. Fish. Aquat. Sci. 48: 2499-2508.

Bisson, P.A., Bilby, R.E., Bryant, M.D., Dollof, C.A., Grette, G.B., House, R.A., Murphy, M.L., Koski, K.V., and Sedell, J.R. 1987. Large woody debris in forest streams in the Pacific Northwest: past, present, and future. In Stream management: forestry and fisheries interaction. Edited by E.O. Salo and T.W. Cundy. Institute of Forest Resources, University of Washington, Seattle. Contrib. 57. pp. 143-190.

Bovis, M.J., Millard, T.H., and Oden, M.E. 1998. Gully processes in coastal British Columbia: the role of woody debris. In Carnation Creek and Queen Charlotte Islands Fish/Forest Interaction Workshop: Applying 20 Years of Coastal Research to Management Solution. Edited by D.L. Hogan, P.J. Tschaplinski, and S. Charwin. Research Branch, B.C. Ministry of Forests, Victoria. Land Manag. Handb. 41. pp. 49-75.

Bryant, M.D. 1980. Evolution of large organic debris after timber harvesting: Maybeso Creek, 1949-1978. USDA For. Serv. Gen. Tech. Rep. PNW-101. 
Bryant, M.D. 1984. Distribution of salmonids in the Trap bay basin, Tenakee Inlet. In Fish and Wildlife Relationships in Old-growth Forests: Proceedings of a Symposium, 12-15 Apr. 1982, Juneau, Alaska. Edited by W.R. Meehan, T.R. Merrell, Jr., and T.A. Hanley. American Institute of Fisheries Research Biology, pp. 17-31.

Frissell, C.A., Liss, W.J., Warren, C.E., and Hurley, M.D. 1986. A hierarchical framework for stream habitat classification: viewing streams in a watershed context. Environ. Manage. 10: 199-214.

Froehlich, H.A. 1973. Natural and man-caused slash in headwater streams. Pacific Logging Congress, Portland, Oreg. Logging Handb. 33.

Harmon, M.E., Franklin, J.F., Swanson, F.J., Sollins, P., Gregory, S.V., Lattin, J.D., Anderson, N.H., Cline, S.P., Aumen, N.G., Sedell, J.R., Lienkaemper, G.W., Cromack, K., and Cummins, K.W. 1986. Ecology of coarse woody debris in temperate ecosystems. Adv. Ecol. Res. 15. pp. 133-302.

Harris, A.S., and Farr, W.A. 1974. The forest ecosystem of southeast Alaska: 7. Forest ecology and timber management. USDA For. Serv. Gen. Tech. Rep. PNW-25.

Hedman, C.W., Van Lear, D.H., and Swank, W.T. 1996. In-stream large woody debris loading and riparian forest serial stage associations in the southern Appalachian Mountains. Can. J. For. Res. 26: 1218-1227.

Heede, B.H. 1972. Influence of a forest on hydraulic geometry of two mountain streams. Water Resour. Bull. 8: 523-530.

Hogan, D.L., Bird, S.A., and Hassan, M.A. 1998. Spatial and temporal evolution of small coastal gravel-bed streams: influence of forest management on channel morphology and fish habitat. In Gavel-bed rivers in the environment. Edited by P.C. Klingeman, R.L. Beschta, P.D. Komar, and J.B. Bradley. Water Resources Publications, Highlands Ranch, Colo. pp. 365-392.

Inoue, M., and Nakano, S. 1998. Effects of woody debris on the habitat of juvenile masu salmon (Oncorhynchus masou) in north Japanese streams. Freshwater Biol. 40: 1-16.

Johnson, A.C., Swanston, D.N., and McGee, K.E. 2000. Landslide initiation, runout, and deposition within clearcuts and old-growth forests of Alaska. J. Am. Water Resour. Assoc. 36(1): 1-14.

Littell, R.C., Milliken, G.A., Stroup, W.W., and Wolfinger, R.D. 1999. SAS system for mixed models. SAS institute Inc., Cary, N.C.

Meehan, W.R., Farr, W.A., Bishop, D.M., and Patric, J.H. 1969. Effects of clear-cutting on salmon habitat of two southeast Alaska streams. USDA For. Serv. Res. Paper PNW-82.

Megahan, W.F. 1982. Channel sediment storage obstruction in forested drainage basins draining the granitic bedrock of Idaho basins. In Sediment budget and routing in forested drainage basins. Edited by F.J. Swanson, R.J. Janda, T. Dunne, and D.N. Swanston. USDA For. Serv. Gen. Tech. Rep. PNW-141. pp. 114-121.

Millard, T. 2000. Channel disturbance and logging slash in S5 and S6 streams - an examination of streams in the Nitinat Lake area, southwest Vancouver Island. B.C. Forest Service, Victoria. For. Res. Tech. Rep. TR-005.

Montgomery, D.R., Buffington, J.M., Smith, R.D., Schmidt, K.M., and Pess, G. 1995. Pool spacing in forest channels. Water Resour. Res. 31: 1097-1105.

Murphy, M.L., and Koshi, K.V. 1989. Input and depletion of woody debris in Alaska streams and implications for streamside management. N. Am. J. Fish. Manage. 9: 423-436.

Murphy, M.L., Heifetz, J., Johnson, S.W., Koski, K.V., and Thedinga, J.F. 1986. Effects of clear-cut logging with and without buffer strips on juvenile salmonids in Alaskan streams. Can. J. Fish. Aqut. 43: 1521-1533.

Naiman, R.J., Bilby, R.E., and Bisson, P.A. 2000. Riparian ecology and management in the Pacific costal rain forest. BioScience, 50(11): 995-1011.
Nakamura, F., and Swanson, F.J. 1993. Effects of course woody debris on morphology and sediment storage in mountain stream system in western Oregon. Earth Surf. Processes Landforms, 18: 43-61.

Nakamura, F., and Swanson, F.J. 1994. Distribution of coarse woody debris in a mountain stream, western Cascade region, Oregon. Can. J. For. Res. 24: 2395-2403.

Neter, J., Kutner, M.H., Nachtsheim, C.J., and Wasserman, W. 1996. Applied linear statistical models. 4th ed. McGraw-Hill, Boston, Mass.

Ralph, S.C., Poole, G.C., Conquest, L.L., and Naiman, R.J. 1994. Stream channel morphology and woody debris in logging and unlogging basins of western Washington. Can. J. Fish. Aquat. Sci. 51: 37-51.

Richardson, J.S. 1992. Food, microhabitat, or both? Macroinvertebrate use of leaf accumulations in a montane stream. Freshwater Biol. 27: 169-176.

Robison, E.G., and Beschta, R.L. 1990. Characteristics of coarse woody debris for several coastal streams of southeast Alaska, U.S.A. Can. J. Fish. Aquat. Sci. 47: 1684-1693.

Sidle, R.C. 1986. Seasonal pattern of allochthonous debris in three riparian zones of a coastal Alaska drainage. In Watershed research prospectives. Edited by D.L. Correll. Smithsonian Institution Press, Washington, D.C. pp. 283-304.

Sidle, R.C., and Sharma, A. 1996. Stream channel changes associated with mining and grazing in the Great Basin. J. Environ. Qual. 22: 1111-1121.

Sidle, R.C., Pearce, A.J., and O'Loughlin, C.L. 1985. Hillslope stability and landuse. American Geophysical Union, Washington, D.C. Water Resour. Monogr. 11.

Strahler, A.N. 1957. Quantitative analysis of watershed geomorphology. Trans. Am. Geophys. Union, 38: 913-920.

Swanson, F.J., Bryant, M.D., Lienkaemper, G.W., and Sedell, J.R. 1984. Organic debris in small streams, Prince of Wales Island, Southeast Alaska. USDA For. Serv. Gen. Tech. Rep. PNW-166.

Swanson, F.J., Johnson S.L., Gregory, S.V., and Acker, S.A. 1998. Flood disturbance in a forested mountain landscape. Bioscience, 48: $681-689$.

Swanston, D.N. 1967. Geology and slope failure in the Maybeso Valley, Prince of Wales Island, Alaska. Ph.D. dissertation, Michigan State University, East Lansing.

Tsukamoto, Y., Ohta, T., and Noguchi, H. 1982. Hydrological and geomorphological study of debris slides on forested hillslope in Japan. IAHS Publ. 137. pp. 89-98.

Vannote, R.L., Minshall, M.G., Cummins, K.W., Sedell, J.R., and Cushing C.E. 1980. The river continuum concept. Can. J. Fish. Aquat. Sci. 37: 130-137.

Wipfli, M.S., and Gregovich, D.P. 2001. Invertebrate and detritus export from fishless headwater streams in southeast Alaska: implication for upland forest management and downstream fishbearing habitat. Freshwater Biol. In press.

Wolman, M.G. 1954. A method of sampling coarse riverbed material. Trans. Am. Geophys. Union, 35: 951-956.

Woodsmith, R.D., and Buffington, J.M. 1996. Multivariate geomorphic analysis of forest streams: implication for assessment of landuse impacts on channel condition. Earth Surf. Processes Landforms, 21: 377-393.

Woodsmith, R.D., and Swanson, F.J. 1997. The influence of large woody debris on forest stream geomorphology. In Proceedings of Management of Landscape Disturbed by Channel Incision. Edited by S.S.Y. Wang, E.J. Langedoen, and F. Douglas Shields, Jr. University of Mississippi, Oxford. pp. 133-138. 